STEFAN KWIATKOWSKI

Uniwersytet Szczeciński

\title{
O PRZYDATNOŚCI KATEGORII HABITUSU W BADANIACH NAD CHRYSTIANIZACJĄ SPOŁECZEŃSTW ZACHODNIOSŁOWIAŃSKICH
}

W badaniach nad chrystianizacją Polski i sąsiednich krajów u schyłku $\mathrm{X}$ w. zaznaczyły się w ostatnim półwieczu dwie drogi wyjaśniania. Pierwsza $\mathrm{z}$ nich została rozwinięta $\mathrm{w}$ związku $\mathrm{z}$ badaniami milenijnymi. Jest ona modernistyczna, nawiązuje do ewolucjonistycznego paradygmatu podkreślającego jedność ludzkiego rodzaju, preferuje wyjaśnianie społecznych i ekonomicznych uwarunkowań chrystianizacji, dążąc do generalizacji. Poszukuje analogii w bliskim sąsiedztwie geograficznym, szczególnie wśród Słowian. Drugi kierunek zmierza do ujęcia chrystianizacji raczej w kategoriach tradycyjnego historyzmu, wzbogaconego o współczesne nurty badawcze, takie jak badania nad memorią, rytuałem, wnikliwszy wgląd w subiektywne motywacje ludzi. Podchodzi się tu nieufnie do determinizmu, za to podkreśla indywidualność i niepowtarzalność ludzkiego działania. Zestawienie obu dróg pozwala jednak rozpoznać pewną lukę pomiędzy tym, co jednostkowe i subiektywne, a sferą wnioskowania wynikającą z mniej lub bardziej określonego determinizmu historycznego.

Przedłożony poniżej postulat polega na wprowadzeniu do tematu rozważań nad człowieczym habitusem i jego odmianami, przede wszystkim w kręgu misjonarzy i chrystianizatorów z jednej strony oraz neofitów $z$ drugiej. Oczywiste jest tu nawiązanie do koncepcji Pierre'a Bourdieu ${ }^{1}$. Społecznie nabyte umiejętności i kompetencje jednostki składają się na jej habitus rozumiany jako matryca postrzegania, szacowania i działania.

${ }^{1}$ P. Bourdieu, Szkic teorii praktyki poprzedzony trzema studiami na temat etnologii Kabylów, Kęty 2007 (oryg. franc. 1972). 
Jednocześnie habitus jest źródłem, z którego wynikają i pochodzą praktyczne wskazania odnośnie do jej funkcjonowania w świecie. Nie tworzą one systemu, za to umożliwiają elastyczność w działaniu. Nie są zatem przydatne dla historyka do interpretacji deterministycznej albo utylitarystycznej. $\mathrm{Z}$ habitusu mogą wynikać zasady i reguły rządzące tkanką społeczną i działaniami człowieka. Można wśród nich wymienić: specyfikę ukształtowania poszczególnych pokoleń, integrację fizycznej istoty człowieka ze sferą nadprzyrodzoną, praktyki społeczne i interakcje jednostki ze społeczeństwem. W przypadku pytania o chrystianizację chodziłoby głównie o ogólniejsze rozumienie spraw boskich i ludzkich, które można zauważyć na pograniczu stref chrześcijańskiej i pogańskiej. Niemożliwa jest całkowita adaptacja pojęcia habitus do historii, jednak należy tu wspomnieć, że prekursorami myśli o dyspozycjach i kompetencjach jednostki wobec otaczającego świata byli m.in. Arystoteles i Tomasz z Akwinu (jako dyspozycja dobrego działania). Bliższe rozpatrywanie habitusu uświadamia aprioryczność osiągalnych na tej podstawie wniosków. Poza obserwacją historyczną musiałyby pozostać dociekania nad całością powstawania zjawiska. Habitus, według twórcy tego pojęcia, miałby się kształtować w toku niedyskursywnego działania. Doświadczenia pomiędzy kolejnymi pokoleniami miałyby być przekazywane dzięki podświadomości. Do analizy zjawiska mogłyby zostać wciągnięte uchwytne źródłowo elementy wyposażenia intelektualnego i duchowego.

Chrystianizacja w średniowieczu przebiegała w niewyobrażalnych współcześnie warunkach. Nie wiemy niemal nic o ludziach tamtych czasów, który żyli na „prapolskich” ziemiach, ponieważ nie zostawili po sobie pisemnych świadectw. Wszelkie wnioskowanie, oparte na retrogresywnej krytyce materiału źródłowego, należałoby uznać w świetle współczesnych poglądów epistemologicznych za przede wszystkim wytwór kulturowy historiografii modernistycznej; uzyskany na tej drodze obraz - nie za „model” czy „rekonstrukcję”, lecz za projekcję naszej współczesnej świadomości. Z tych samych względów trudny jest do zaakceptowania historiograficzny obraz społeczeństwa tamtych czasów, oparty na „naukowym” dyskursie, zatem na wytworze kultury naszych czasów. Tkwi on w wielopokoleniowej tradycji historiograficznych dociekań, poszerzanych o rosnącą ciągle domieszkę założeń uprzednich, pobieranych z socjologii, antropologii i innych dziedzin nauki.

Wśród mediewistów można dostrzec dążenie do wytwarzania możliwie pełnego obrazu chrystianizacji, w czym niezastąpione usługi oddają sądy aprioryczne. W przyjętej powszechnie procesualnej narracji zwykle można odnaleźć nomologiczno-dedukcyjny model wyjaśniania. Najwięcej paradygmatycznego materiału dostarcza ewolucjonistyczna 
koncepcja dziejów i człowieka. W okresie powojennych dziesięcioleci narzucono na nią matrycę marksistowską. Po splocie wymienionych perspektyw pozostało w tradycji dziejopisarskiej przekonanie, wyrażane mniej lub bardziej otwarcie, o znaczeniu materialnych podstaw społeczeństwa w kształtowaniu jego kulturowej sfery. Pozostaje w użyciu paradygmat rozwojowy.

Kiedy przebrzmiały modernistyczne ujęcia z okresu badań „milenijnych", chrystianizację Polski, szczególnie jej etap w X-XI w., zwykło się w mediewistyce opisywać z równie jednostronnej perspektywy władcy-neofity i jego państwa. Niewątpliwe polityczne motywy decyzji o przyjęciu chrztu sprawiają, że studia nad społeczno-moralnym zjawiskiem chrystianizacji zwróciły się ku instytucjonalnym aspektom, przez co w centrum uwagi pozostawała monarchia, organizacja kościelna, zmiany prawne. Często do procedury wyjaśniającej dołączano elementy dyfuzjonistycznej koncepcji przemiany kulturowej. Niewyczerpywalnym zasobem były tu oczywiście analogie zachodnio- i wschodniosłowiańskie. W ostatnim ćwierćwieczu odeszły one na dalszy plan, a na ich miejsce, jako równouprawnione, weszły analogie frankońskie, anglosaskie, longobardzkie, skandynawskie i saskie.

Historiografia realistyczna mniej lub bardziej otwarcie opiera się na wierze w dostępność dziejów badaniu historycznemu, odwołując się do klasycznego historyzmu. Jej podstawą pozostaje hermeneutyczna analiza źródła, wynikająca po części z ubóstwa źródeł. Łatwo dostrzec występujące w niej implicite założenia uprzednie, wywodzące się z rozmaitych kręgów myślowych humanistyki. Najsłabszym punktem może tu się okazać nadmierna dążność do „ustaleń”, mających wykazać odrębny wkład w chrystianizację poszczególnych władców i ludzi Kościoła. Szersze uwzględnienie realiów epoki, takich jak słabo rozwinięte systemy komunikacji społecznej oraz ograniczoność horyzontów, która cechowała przytłaczającą większość katechumenów, może skutecznie osłabiać wiarygodność tego rodzaju dociekań i rozważań.

Widoczna warstwa założeń uprzednich wynika często ze stosunku współczesnego badacza do religii. Dyskurs o historycznym znaczeniu chrześcijaństwa przybierał rozmaite treści - od apologetycznych do krytycznych - które oddziałują do dziś, mimo obowiązującego ideału obiektywności. W praktyce stosuje się milczące założenie, według którego materię historyczną dzieli się (według paradygmatu wynalezionego przez średniowiecznych kanonistów) na spiritualia i temporalia. Historyk zajmuje się tylko doczesną dziedziną. Wobec działu spiritualia zachowuje się neutralność, a ponadto wychodzi z założenia, że treści niesione z chrystianizacją były zgodne ze współczesną nam doktryną 
katolicką. Rozdzielne traktowanie obu sfer nie przyczynia się to do rozwiązania problemów, które powstają z związku z postulatem rozumiejącego ujęcia dziejowej rzeczywistości.

Za bezsporne uchodzi przekonanie, że najważniejszym efektem chrystianizacji było kształtowanie się w długotrwałym procesie nowego człowieka i współtworzonej przez niego nowej rzeczywistości. Już kilka pokoleń mediewistów formułowało własne (uwarunkowane kulturowo) opinie na ten temat, jednak w odniesieniu do ogólnego wymiaru zjawiska osiągane rezultaty ukazują swą historyczność i przemijającą aktualność. Poprzez pojęcie habitusu istnieje szansa otwarcia się na wiedzę potoczną, podzielaną w określonej grupie/środowisku, stanowiącą (jako wytwór określonego środowiska) podstawę standaryzacji pewnych rodzajów zachowań. W poszukiwaniu ujęcia istoty habitusu warto zwrócić uwagę na dwa niedoceniane aspekty:

- pierwszym z nich jest środowisko misjonarzy wraz z uwzględnieniem (na ile się da) występujących wśród krzewicieli wiary odmiennych formacji duchowych, intencji, sposobów działania;

- drugim - postulat określenia pewnego habitusu katechumena i neofity.

Mimo stosunkowo wiarogodnej podstawy źródłowej przedstawiciele obu wymienionych kręgów ukazywani są w historiografii schematycznie i mało przekonująco. Do kwestii duchowej sylwetki misjonarzy istnieje stosunkowo obszerny materiał źródłowy (głównie hagiograficzny), niedostatecznie wykorzystany w dotychczasowych opracowaniach. Dla określenia habitusu pogan i neofitów dysponujemy ogromnym materiałem antropologicznym i archeologicznym, znajdującym tylko częściowe albo marginalne zastosowanie w badaniach nad chrystianizacją.

Podjęcie misji w barbarzyńskiej Europie rozumiane było, najogólniej rzecz ujmując, jako powołanie do współpracy w dziele prowadzenia ludzkości do zbawienia. Lecz sama idea ulegała środowiskowym mutacjom. Misjonarze Grzegorza Wielkiego reprezentowali Rzym i antyczny jeszcze uniwersalizm. Władztwo Merowingów odwoływało się do tradycji kościelnej istniejącej w granicach dawnego imperium. Należałoby przyjąć, że w dawnej Germanii ukształtowała się dość surowa forma religijności, w wielu szczegółach odległa od śródziemnomorskich prawzorów. Na wschodniej granicy krajów (po)karolińskich została na nowo ustalona granica chrześcijaństwa, skrystalizował się i zaostrzył podział na christiani i barbari. W wieku X misja, jako apel o współdziałanie w dziele zbawienia, kierowana była do ludzi, którzy wcześniej wśród chrześcijan budzili tylko strach i pogardę, czasem współczucie i politowanie. Można przypuszczać, że dość powszechnie panowało przeświadczenie o istnieniu 
nieprzezwyciężalnej bariery pomiędzy chrześcijańskim życiem a wolną egzystencją barbarzyńców, wykluczonych ze społeczności Bożej. Wobec społeczności chrześcijańskich barbari występowali albo jako najeźdźcy lub rabusie, albo brańcy, względnie jako niewolnicy przeznaczeni na handel (w mniej lub bardziej otwartej formie). Jeśli na pograniczu z wolna otwierały się międzyludzkie kontakty, kształtowały się formy kooperacji i współpracy z barbari, to nie musiały stosować się do zasad partnerstwa i równości, ale raczej podporządkowania i dominacji.

W tej sytuacji ważnym przełomem było odnowienie misyjnych idei w X w. Świat barbarzyński miał zostać pozyskany dla budowania na ziemi ładu zgodnego z prawami Bożymi, a w perspektywie eschatologicznej do prowadzenia możliwie najszerszych rzesz wiernych do zbawienia. Odnowione idee misyjne w najbardziej efektywnej formie wcielane były w życie przez prozelitów, gotowych do poświęcenia życia w imię wiary. Byli oni rygorystyczni wobec współwyznawców, a jednocześnie otwarci na barbari, gdyż widzieli w nich dzieci Boże. Odmienną postawę można zauważyć wśród administratorów Kościoła, pragmatyków ewangelizacji. Można ją przypisać biskupowi praskiemu Dytmarowi, poprzednikowi Wojciecha, czy merseburskimu Thietmarowi.

Chrystianizacja w X-XI w. miała oparcie w paradygmatycznym myśleniu i interpretowaniu świata, charakterystycznym dla epoki. Odnalezienie związków pomiędzy obowiązującymi kategoriami myślowymi wśród średniowiecznych elit intelektualnych (zatem ludzi Kościoła) a podstawami ideowymi misji możliwe jest w zasadzie na gruncie hipotez. Jednak z tym problemem boryka się także historiografia poświęcona zagadnieniom politycznym i instytucjonalnym, co nie dyskredytuje studiów z tego zakresu. Oczywiście źródłowe świadectwa do dziejów chrystianizacji regionu w X-XI w. nie mają wiele wspólnego z filozoficznymi traktatami. Zresztą stan filozofii na Zachodzie w tym momencie pozwalał jedynie na określanie podstaw porządków nadprzyrodzonego i stworzonego. Neoplatońskie widzenie świata, zawdzięczające swoje miejsce w myśli teologicznej dziełom przede wszystkim Pseudo-Dionizego i św. Augustyna, stało się podwaliną tożsamości chrześcijańskiego Zachodu. W epoce karolińskiej teologowie wiele wysiłku włożyli w zgłębianie podstaw tego kierunku, choć niewiele wiadomo o drogach jego recepcji. Można za to stwierdzić powszechną obecność idei neoplatońskich w twórczości pisarzy krajów pokarolińskich.

Wstępnie tylko warto zwrócić uwagę na niektóre paradygmatyczne wątki myślowe, które wolno powiązać ze środowiskiem misyjnym. $\mathrm{Na}$ rozumienie relacji panujących na styku chrześcijaństwa i barbaricum wielki wpływ miało przekonanie o hierarchicznym porządku świata 
bytów duchowych i cielesnych, zróżnicowanych w obu kategoriach pod względem doskonałości. Według niego emanacja najwyższego dobra dokonywała się po stopniach hierarchii bytów duchowych i stojących niżej, materialnych. Stosownie do tego ludzkości przypisywano hierarchiczny porządek, w którym pogan widziano na najniższym miejscu jako ludzi pozbawionych więzi z Bogiem.

Poznanie rozumowe miałoby być osiągalne dzięki iluminacji bożej. Wstęp do Vita quinque fratrum Brunona z Kwerfurtu reprezentuje typ mistyki zbliżony do Eriugeny, który głosił, że wiara warunkuje Objawienie. Umysł niższy dawałby orientację tylko w rzeczach cielesnych, a dopiero jego wyższa forma, wspomagana przez łaskę, umożliwiałaby dotarcie do idei Bożych i Boga. Poganie mieliby być niewolnikami grzechu i świata materialnego. Kler z pogranicza oraz misjonarze zapewne podzielali pogląd,jakoby umysł ludzki nie był sam z siebie zdolny do pojęcia istoty Boga. W tych okolicznościach możliwości neofitów w ogarnięciu wartości duchowych musiały być oceniane nisko. To może wyjaśniać, dlaczego łatwo godzono się z płytkością konwersji, jak również to, dlaczego współdziałanie w dziele prowadzenia ludzi do zbawienia miałoby się odbywać z zachowaniem hierarchicznego porządku i przy akceptacji pewnego upośledzenia nowo nawróconych.

Jeszcze istotniejsza dla chrześcijańskiego rozumienia kondycji pogan jest augustyńska koncepcja człowieka, żywa w praktyce duszpasterskiej kościoła pokarolińskiego. Wszelkie dobro i rozum miałyby pochodzić bezpośrednio od Boga. Człowiek ze swej natury miałby być zdolny jedynie do czynienia zła, do grzechu, co dobitnie wyrażał Bruno z Kwerfurtu. Skłonności do czynienia dobra miałyby pochodzić od Boga, jako pochodzące z zewnątrz. Bruno, zwracając się do Boga, prosi, by go wspomógł w opisie rzeczy świętych, by powołał go do spełnienia swych zamiarów jako „przewrotnego grzesznika”.

W neoplatońskiej hierarchii oddziaływać na siebie mogły jedynie byty znajdujące się w bezpośrednim sąsiedztwie. Tak samo miałyby działać hierarchie wśród ludzi. Podstawą było przekonanie o podziale ludzi na tych, którzy żyją dla Boga i w ścisłym z nim związku (uświęconych, ale także podzielonych w hierarchicznej skali), oraz na profanów, dopuszczanych do sfery sakralnej stosownie do ich społecznego miejsca i prestiżu. Odpowiedzialnością za powodzenie misji po stronie neofitów byli obarczani profani - władcy oraz ich elitarne otoczenie, integrowani z kluniacką formą pobożności. Członkom kręgów przywódczych, jako pragmatykom ewangelizacji, narzucano wygórowane warunki. Ustanawiali oni pobożne fundacje, w zamian byli przyjmowani do modlitewnych wspólnot, a po śmierci grzebani uroczyście w miejscach nowego kultu. Synowie najznamienitszych rodów wstępowali, a raczej byli tam kierowani, na służbę Kościoła. 
W świecie barbarzyńskim obcość świata była powszechnym doznaniem, kojarzonym z wrogością i zagrożeniem. Dla neofitów nowym punktem odniesienia stawała się jedność chrześcijan. Wiara w jednego, wszechmocnego Boga - ojca wszystkich ludzi - pozwalała,jak można zakładać, na inną niż dawniej otwartość na zewnętrzny świat i możliwości współpracy. W historiografii zwykło się przypisywać nowej religii integracyjną rolę w procesie kształtowania się „narodów” albo w budowaniu spoistości władztw środkowo- i wschodnioeuropejskich dynastii. Dyskusja na temat Piastów ogranicza się de facto do tego, czy Mieszko I lub Bolesław Chrobry mogli łączyć z nową religią cele integracyjne. Równie dobrze można by zapytać, czy nie żywili oni obaw, że ich ochrzczeni poddani utracą swą tożsamość na rzecz bardziej uniwersalnej, bo ogólnochrześcijańskiej. Właśnie ten motyw, stale obecny w źródłach, jest niedostatecznie uwzględniony w interpretacjach i wnioskowaniach. Eschatologiczny cel znajdował się poza lokalnym horyzontem. Fundacje książąt z nowo schrystianizowanych rodów dla zagranicznych instytucji kościelnych i modlitewnych wspólnot mogą być odzwierciedleniem przewartościowania w tym zakresie. Przyswojenie uniwersalnej, jednakowo dostępnej każdemu człowiekowi perspektywy eschatologicznej zostało urzeczywistnione w wyniku pogłębionej ewangelizacji, dokonywanej w ciągu paru pokoleń. Lecz ta otwartość powodowała osłabianie dawnych tożsamości etnicznych i kulturowych.

$\mathrm{Z}$ przyjęciem nowej religii zmieniało się rozumienie panowania nad ludźmi i relacji międzyludzkich. Istotny wkład wniosła w tym zakresie sakralizacja władzy monarszej, którą przyniosło chrześcijaństwo, oraz zadania nakładane na chrześcijańskiego monarchę. Pozostaje niedoceniony wpływ nowej religii na stosunek pomiędzy „panem” i jego „człowiekiem”. Wśród pogan i neofitów stosunki międzyludzkie „regulowała” brutalna przemoc w zakresie o wiele większym niż w społecznościach schrystianizowanych. Fundamentem etyki nowo nawróconych stawało się założenie (trzeba przyznać, że odległe mentalnie od wcześniejszej tradycji kulturowej), zgodnie z którym ludzi uznaje za dzieci Boże i nie wolno ich zawłaszczać ani zniewalać w imię ziemskich celów. Święty Wojciech miał cierpieć z powodu sprzedawania w niewolę chrześcijan; nie ludzi, lecz właśnie chrześcijan. Mogło by stąd wynikać, że w wyniku chrystianizacji w państwach Przemyślidów i Piastów wprowadzano (w niesprzyjających okolicznościach) zakaz pozbawiania wolności neofitów oraz traktowania niewolnych jako czyjejkolwiek własności. Bruno z Kwerfurtu za jedną z głównych zasług misjonarskich poczytuje uwalnianie ludzi z okowów, zapewne za aprobatą księcia Polan. Uznanie ludzkiej godności mogło być jednym z bardziej atrakcyjnych i zarazem spornych innowacji misji. Jest bardzo prawdopodobne, że misjonarze starali się uświadomić neofickim władcom 
ograniczony charakter ich panowania nad człowiekiem. Św. Wojciechowi, a zapewne także innym głosicielom wiary, mogło to sprawiać trudność nie do pokonania. Ważnym aspektem była negacja zakorzenionego w kulturach barbarzyńskich zwyczaju zemsty przez ideę przebaczenia. Kościół karoliński przy współpracy z monarchią dążył do ograniczenia zemsty przez regulacje prawne oraz przez szerzenie ewangelizacji. Św. Wojciech próbował daremnie ocalić przed prawem zemsty tylko bezbronną kobietę. Zapewne jego ingerencja w szersze porachunki pomiędzy prażanami byłaby bez szans. Warto jednak przypomnieć, że szczupły krąg benedyktyński skupiony wokół domu zakonnego w Kaźmierzu, zapewne w imię idei przebaczania, wymógł na Bolesławie Chrobrym darowanie życia zabójcom Pięciu Braci i umożliwienie im pokuty za dokonaną zbrodnię.

Chrystianizacja, bez względu na jakość i głębię ewangelizacji, zawierała w sobie podstawy wzajemnego zrozumienia, miłosierdzia i przebaczania, które regulować miały współżycie w doczesnym wymiarze. Religia tworzyła wspólną płaszczyznę współpracy między ludźmi, ramę współdziałania w nader często powtarzanej, niedocenianej przez historyka, formule: In nomine Domini. Nie powinno się rozumieć jej anachronicznie. Za formułą tą stała bowiem akceptacja dla całego wyposażenia mentalnego ludzi epoki, w którym na trwałe istniało przeświadczenie o względnej tylko równości ludzi wobec Boga. Na gruncie społecznym zapewne pozwalało to na ustanawianie przez zwierzchność form dominacji człowieka nad człowiekiem, na szeroki margines dyskryminacji i ucisku, zjawisk stale obecnych w średniowieczu. 